\title{
The Cajal school and the physiological role of astrocytes: a way of thinking
}

\author{
Marta Navarrete ${ }^{1}$ and Alfonso Araque ${ }^{1,2 *}$ \\ Functional and Systems Neurobiology, Instituto Cajal, CSIC, Madrid, Spain \\ ${ }^{2}$ Department of Neuroscience, University of Minnesota, Minneapolis, MN, USA
}

\section{Edited by:}

Fernando De Castro, Hospital

Nacional de Parapléjicos-SESCAM,

Spain

Reviewed by:

João G. Franca, Universidade

Federal do Rio de Janeiro, Brazil

George W. Huntley, Icahn School of

Medicine at Mount Sinai, USA

*Correspondence:

Alfonso Araque, Department of

Neuroscience, University of

Minnesota, 4-110 Wallin Medical

Biosciences Building, 2101 6th

Street SE, Minneapolis, MN 55455,

USA

e-mail: araque@umn.edu
Cajal is widely recognized by the scientific community for his important contributions to our knowledge of the neuronal organization of the nervous system. His studies on neuroglial cells are less recognized, yet they are no less relevant to our current understanding of the cellular bases of brain structure. Two pioneering studies published a century ago - "Something about the physiological significance of neuroglia" (Ramón y Cajal, 1897) and "A contribution to the understanding of neuroglia in the human brain" (Ramón y Cajal, 1913)—focused on glial cells and their role in brain physiology. Novel findings obtained using state-of-the-art and sophisticated technologies largely confirm many of the groundbreaking hypotheses proposed by Cajal related to the structural-functional properties of neuroglia. Here we propose to the reader a journey guided by the ideas of Cajal through the recent findings on the functional significance of astrocytes, the most abundant neuroglial cell type in the nervous system. Astrocyte-neuron interaction, which represents an emerging field in current neuroscience with important implications for our understanding of the cellular processes underlying brain function, has its roots in many of the original concepts proposed by Cajal.

Keywords: astrocytes, neuron-glia communication, Cajal, tripartite synapses, gliotransmission
One hundred years ago Cajal published two studies centered on glial cells: "Algo sobre la significación functional de la neuroglia" (Something about the physiological significance of neuroglia) in 1897 and "Contribución al conocimiento de la neuroglia del cerebro humano" (A contribution to the understanding of neuroglia of the human brain) in 1913, which proposed pioneering concepts regarding the relevance of glial cells in brain function that in many instances have been confirmed by recent evidence obtained using novel and sophisticated techniques. In this article, we propose to the reader a voyage starting from Cajal's original ideas to the most recent evidence revealing the functional significance of the neuroglia. While we will see how he opened new venues for the understanding of neuroglia and how his ideas have been largely confirmed by later studies, he must not be considered a scientific visionary; rather, he had an unparalleled capacity to extract general and dynamic physiological conclusions from observations of static images (Figure 1).

¿"Qué significación funcional debemos otorgar a la neuroglía? Desgraciadamente, en el estado actual de la ciencia no es posible contestar a la importante pregunta más que mediante conjeturas más o menos racionales. En presencia de este problema, el fisiólogo se halla, por falta de métodos, totalmente desarmado"

What functional significance can be attributed to the neuroglia? Unfortunately, the present state of science does not allow to answer this important question but through more or less rational conjectures. When facing this problem, the physiologist is totally disarmed for lack of methods (Ramón y Cajal, 1899).

This sentence reflects the incipient state of the technology at the end of the nineteenth century, which, however, did not prevent him from proposing ideas and hypotheses that were not fully misguided. At that time, one of the prevailing ideas concerning the function of glial cells postulated that they served to provide structural consistency to the nervous system in areas not occupied by neurons. In contrast, Cajal disagreed with this simple function ascribed to the neuroglia: ¿Qué van a sostener corpúsculos pequeñisimos, aislados, flexibles, delicadísimos, mucho más delicados y pequeños que las células nerviosas mismas? (What could hold these tiny, isolated, flexible, very delicate cells, much more delicate and smaller than the nerve cells?) (Ramón y Cajal, 1895). In contrast, he proposed the insulation theory, that is, that astrocytes would serve as cellular insulators that separated the activity of neighboring neurons. While this hypothesis was not confirmed by subsequent studies, it is noteworthy that it was probably the first time that a direct involvement of astrocytes in neuronal function was proposed. Indeed, Cajal indicated "No estimamos las hipótesis que acabamos de exponer como teorías exentas de reproche. Pero no por esto las hipótesis racionales, que tienen su punto de partida en algunos hechos conocidos, dejan de ser legitimas y hasta fecundas. Una hipótesis científica representa una dirección nueva, un camino que se traza a la observación y a la experimentación, el cual, si no conduce inmediatamente a la verdad, suscita siempre investigaciones y críticas que nos aproximan a ella" (We do not consider this hypothesis exempt from reproach. But rational hypotheses based on some actual facts are legitimate and even fruitful. A scientific hypothesis represents a new direction, a path traced for observation and experimentation, which, if it does not immediately lead to the truth, always raises 


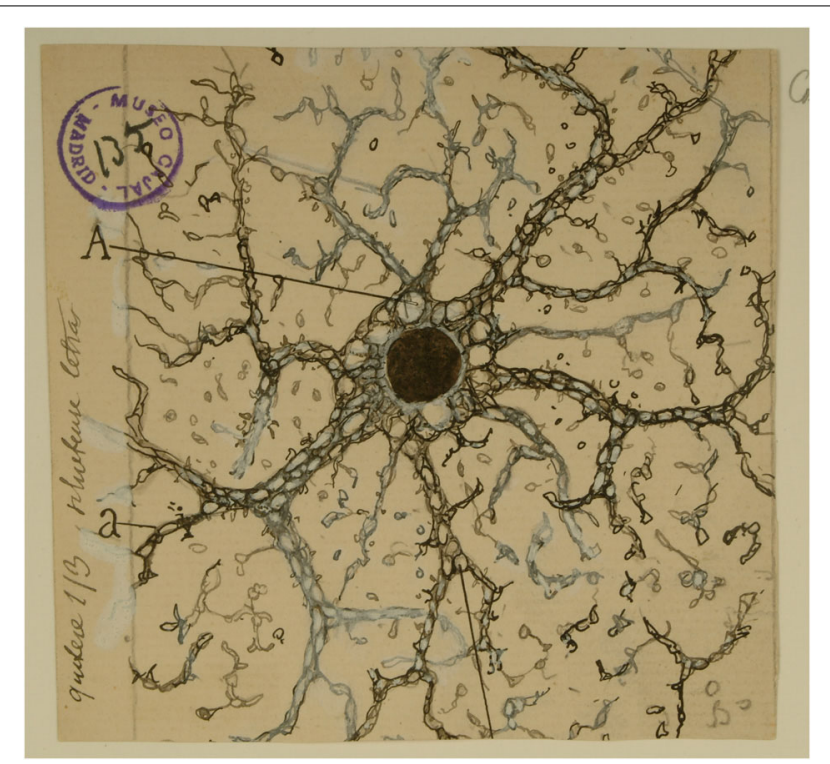

FIGURE 1 | Cajal's drawing showing a "neuroglia" of the pyramidal layer and stratum radiatum of the Ammon horn from adult man autopsied $\mathbf{3} \mathbf{h}$ after death. (A) Indicates the large vacuoles of the soma; (a and b), the gaps of the expansions intended for the gliosomas. Reproduced from an original drawing, with permission of the Instituto Cajal.

investigations and criticisms that bring us closer to it) (Ramón y Cajal, 1895).

In the 1980s, cellular biology and neuroscience underwent a technological revolution led by the development and use of novel tools such as the patch-clamp technique, fluorescence imaging, and confocal and multiphoton microscopy, which allowed the detailed visualization of structural properties and physiological processes of cells. Using these novel techniques, the physiologist was no longer unarmed but rather endowed with an arsenal of potent tools to investigate the function of astrocytes. Until then, astrocytes were considered to simply provide trophic and structural support for neurons. This Nutrition Theory originally proposed by Golgi (1903) has been consistently confirmed, and astrocytes are recognized as fundamental cells providing the necessary metabolic and nutritional support for the proper development and function of neurons (for a review see, e.g., Bélanger et al., 2011). However, this theory limited the function of astrocytes to a passive role without direct involvement in information processing in the brain. Nevertheless, recent evidence indicates astrocytic glycogen breakdown and lactate release is essential for the maintenance of long-term synaptic strength, suggesting that metabolic support from astrocytes is required for long-term memory formation (Suzuki et al., 2011).

The idea that astrocytes play passive roles in brain function probably derived from the fact that electricity is the main biophysical substrate underlying brain physiology. While neurons use electrical events to convey information, astrocytes are not electrically excitable cells. Furthermore, neurons were recognized to be directly in contact with the external world, receiving information from the sensory organs and transmitting information to endocrine organs and muscles. In contrast, astrocytes are confined to the central nervous system without direct physical communication with the environment. However, the use of fluorescence microscopy and calcium-sensitive fluorescent dyes in the decade of 1990s revealed that astrocytes display cellular excitability based not on electrical events but on variations in intracellular calcium concentration (Cornell-Bell et al., 1990; Charles et al., 1991; Perea and Araque, 2006; Perea et al., 2009; Zorec et al., 2012), which serve as cellular signals with important consequences for the physiology of the nervous system. Indeed, transient variations in cytosolic calcium in astrocytes occur spontaneously, but more importantly, they can also be evoked by synaptic activity and sensory stimuli, indicating that astrocytes sense neuronal activity and synaptic transmission (Wang et al., 2006; Perea et al., 2009; Takata et al., 2011; Navarrete et al., 2012; Araque et al., 2014). Indeed, astrocytes express several G proteincoupled neurotransmitter receptors, which upon stimulation activate phospholipase $\mathrm{C}$ leading to inositol triphosphate $\left(\mathrm{IP}_{3}\right)$ production and calcium mobilization from internal stores. This astrocyte calcium signal can be elicited by a wide variety of neurotransmitters released from synaptic terminals, such as glutamate, gamma-aminobutyric acid (GABA), norepinephrine, dopamine, acetylcholine, serotonin, adenosine triphosphate (ATP) and nitric oxide (for reviews see Perea et al., 2009; Araque et al., 2014). Endocannabinoids released from postsynaptic neurons can also signal to astrocytes (Navarrete and Araque, 2008, 2010; Min and Nevian, 2012).

Consequently, astrocytes are now recognized to receive signals from neurons, actively responding to neuronal and synaptic activity with cytosolic calcium elevations evoked by neurotransmitters.

While synaptic activity is the input signal detected by astrocytes, what is the output of the astrocytic activity and what are its functional consequences?

"La neuroglía de la substancia gris vendría a constituir una vasta glándula endocrina intercalada entre las neuronas y plexos nerviosos, destinada quizás a elaborar hormonas asociadas a la actividad cerebral" (The gray matter neuroglia would constitute a vast endocrine gland intertwined with neurons and nerve plexus, intended perhaps to produce hormones associated with the brain activity) (Ramón y Cajal, 1913).

Accumulating evidence obtained in the last 15 years has confirmed this original idea expressed by Cajal. Indeed, astrocytes can release neuroactive substances, called gliotransmitters, which include glutamate, GABA, ATP/adenosine, or D-serine (for reviews see Volterra and Meldolesi, 2005; Perea et al., 2009; Araque et al., 2014). These gliotransmitters may activate receptors in neurons, exerting different and complex effects depending on the neuronal receptor subtypes activated and their pre- or postsynaptic localization, that result in the regulation of the neuronal excitability and synaptic transmission and plasticity (Volterra and Meldolesi, 2005; Perea and Araque, 2010; Araque et al., 2014). Moreover, astrocyte signaling can regulate neural network function (Porto-Pazos et al., 2011), as recently described in the cortex where astrocytes regulate UP states (Poskanzer and Yuste, 2011; for a review see Araque and Navarrete, 2010) (Figure 2).

Evidence demonstrating the calcium-based astrocytic excitability elicited by synaptic activity and the 
A

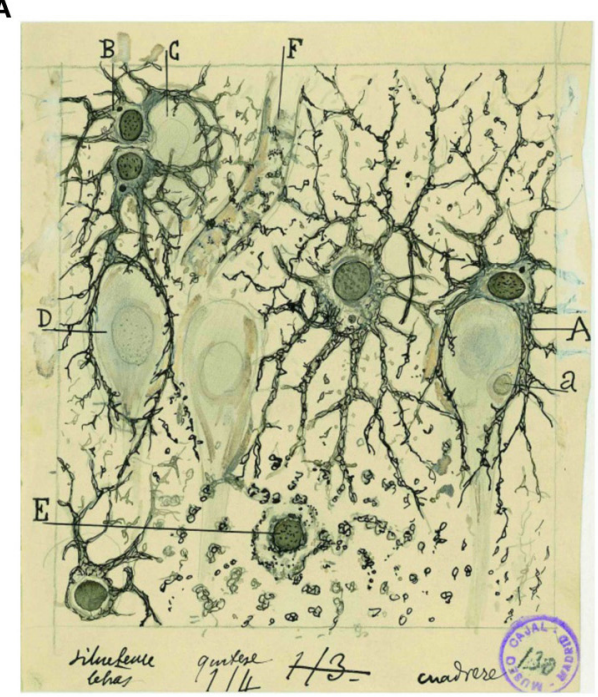

B

\section{TRIPARTITE SYNAPSES}

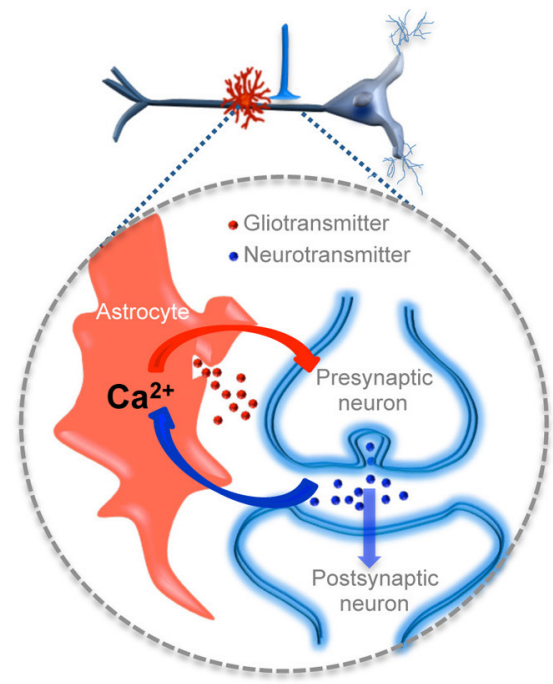

prototypical pyramidal neuron and an astrocyte located close to it (in red). The large dashed circle illustrate an enlarged schematic view of the tripartite synapse, where the pre- and postsynaptic neuronal elements (in blue) are surrounded by astrocytic processes (in red). It also depicts the transfer of information between neuronal synaptic elements and astrocytic processes. Astrocytes respond with $\mathrm{Ca}^{2+}$ elevations to neurotransmitters (blue dots) released during synaptic activity and, in turn, control neuronal excitability and synaptic transmission through the $\mathrm{Ca}^{2+}$-dependent release of gliotransmitters (red dots) calcium-dependent release of gliotransmitters that control synaptic transmission and plasticity has led to the establishment of a new concept in synaptic physiology, the Tripartite Synapse, in which astrocytes are integral elements of the synapses and actively exchange information with the neuronal elements (Araque et al., 1999; Halassa et al., 2009; Perea et al., 2009). This concept implies that the astrocytes directly play active roles in the transfer and storage of information in the brain and that the coordinated action of both neurons and astrocytes are involved in brain function.

Therefore, recent experimental findings regarding astrocyte physiology are in agreement with the original ideas expressed by Cajal based on observations of purely morphological data and on acute interpretation of those observations. Indeed, as he noted in 1897, "Ciertos focos grises, ricos en plexos de expansiones dendríticas y de arborizaciones nerviosas, contienen muchas fibrillas de neuroglía $y$, al revés, ciertos focos pobres en dichos apéndices, son asimismo escasos en corpúsculos de Deiters o neuróglicos [astrocitos]" and "La neuroglía abunda donde las conexiones intercelulares son numerosas y complicadas, y no por el hecho de existir contactos, sino con la mira de reglarlos y dirigirlos de manera que cada expansión protoplásmica solo se ponga en relación intima con un grupo especial de ramificaciones nerviosas terminales" (Certain gray nuclei enriched with plexus of dendritic expansions and nerve arborizations contain many neuroglia fibrils and, conversely, certain nuclei containing few of these appendices are also scarce in Deiters or neuroglia corpuscles [astrocytes] and the neuroglia is abundant where intercellular connections are numerous and complicated, not due to the existence of contacts, but rather to regulate and control them, in such a manner that each protoplasmic expansion is in an intimate relationship with only a particular group of nerve terminal branches) (Ramón y Cajal, 1897).

Besides the intimate contact of astrocytes with synapses, they are also in close contact with blood vessels and capillaries. Cajal also proposed the physiological importance of astrocytes in the regulation of brain microcirculation.

"Todo astrocito de la substancia blanca o gris está provisto de un aparato chupador o pedículo perivascular. El aparato chupador constituye no sólo una disposición constante de los astrocitos de la substancia blanca, sino uno de los factores neuróglicos más importantes de los centros. Semejante generalidad, junto con el hecho de que en los animales de pequeña talla (conejo, cobaya, etc.), y en los en curso de evolución (perro y gato de pocos días), el órgano chupador constituye la más espesa, y a veces la única expansión perceptible y bien coloreable del astrocito denotan que el susodicho apéndice debe desempeñar cometido fisiológico de primer orden."

(Every astrocyte of the white or gray matter is provided with a sucking apparatus or perivascular pedicle [end foot]. The end foot is not only a constant characteristic of astrocytes in the white matter, but one of the most important neuroglial factors in the centers. Such generality, along with the fact that in small animals (rabbit, guinea pig, etc.) and in developing animals (few day-old cats and dogs) the 
end foot is the thickest, and sometimes the only perceptible and wellstained expansion of the astrocyte, indicates that such an appendage must play a first-order physiological role) (Ramón y Cajal, 1913).

"El objeto de tales elementos es suscitar, por contracción de los referidos apéndices, dilataciones locales de los vasos, y, por ende, congestiones fisiológicas ligadas a la mayor o menor intensidad de los procesos psíquicos."

(The purpose of these elements is to provoke, by contraction of such appendages, local dilation of the vessels, and thus physiological congestions linked to the intensity of the mental processes) (Ramón y Cajal, 1895).

Astrocytes are currently recognized as key elements involved in the regulation of brain capillary blood flow during functional hyperemia, that is, the local increase in blood flow produced during neuronal activity that allows the local delivery of oxygen and nutrients in functionally active brain regions with greater energetic requirements. Indeed, recent findings have shown that regional increases in astrocyte calcium levels, produced by neurotransmitter release during neuronal and synaptic activity, stimulate the release of gliotransmitters and vaso-active compounds that regulate localized dilation or constriction of brain capillaries (for recent reviews see Iadecola and Nedergaard, 2007; Carmignoto and Gomez-Gonzalo, 2010; Petzold and Murthy, 2011; Newman, 2013) (Figure 3), providing compelling evidence for Cajal's idea proposed more than a hundred years ago.

"La corteza cerebral humana discrepa de la de los animales, no sólo por la cantidad enorme de células de tipo glandular que contiene, sino por la pequeñez de éstas y la riqueza del plexo gliomatoso intersticial." (The human brain cortex differs from that of other animals not only in the huge amount of glandular cells [astrocytes] that contains, but in their smallness and the wealth of the interstitial glial plexus) (Ramón y Cajal, 1913).

This initial observation made by Cajal has also been confirmed by recent evidence showing that human neocortical astrocytes are larger and extend more primary processes than those of non-primate mammals (Oberheim et al., 2006, 2009; Matyash and Kettenmann, 2010). Moreover, some special anatomically defined subclasses of astrocytes are specifically present in the human neocortex (Oberheim et al., 2009). Based on this evidence, it has been proposed that astrocytic complexity has permitted the increased functional competence of the adult human brain (Oberheim et al., 2006, 2009; Navarrete et al., 2013). In addition and in agreement with Cajal's idea, it is noteworthy that the ratio between glial cells vs. neurons increases along the phylogenetic scale, e.g., from around 0.1 in nematodes to around 10 in primates (Sherwood et al., 2006; Herculano-Houzel, 2012; Lewitus et al., 2012). Although an exhaustive quantification is still lacking, the high number of glial cells in mammals with superior brain functions may be indicative that astrocytes may provide a greater degree of complexity and computational capacity to the brain. Likewise, it is noteworthy that during human evolution, the brain size increased around 300\% with respect to its primitive ancestors, whereas the number of neurons only increased by $125 \%$ (De Felipe, 2011). Therefore, the major difference in brain volume between humans and primates is not only due to a higher development of the neuronal neuropil but also to a higher number and complexity of

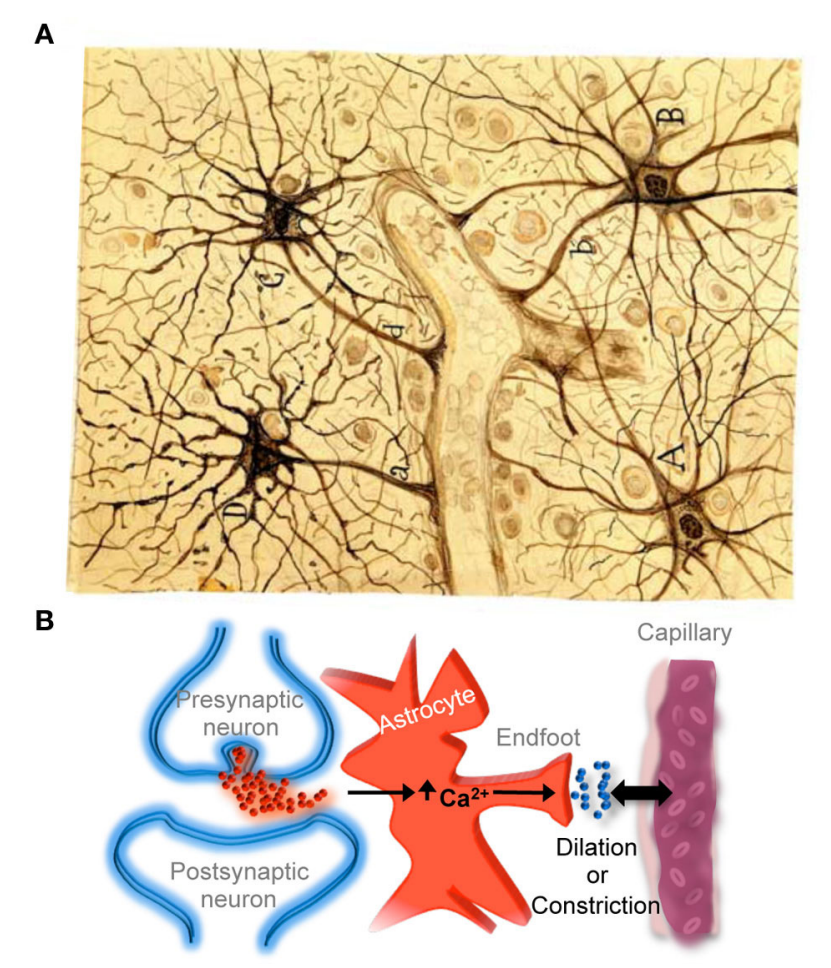

FIGURE 3 | Astrocyte-mediated control of neurovascular coupling. (A) Cajal's drawing of fibrous astrocytes of human cerebral cortex surrounding a blood vessel. The original slide was impregnated by the sublimated gold chloride method. Reproduced from an original drawing, with permission of the Instituto Cajal. (B) Scheme illustrating that neuronal synaptic activity can signal astrocytes to regulate cerebral microcirculation. It should be noted that much of the neurovascular coupling is achieved through effects on smooth muscle cells that are present in arterioles but not in capillaries.

astrocytes. Perhaps what makes us human is in part due to astrocytes.

In conclusion, the naïve notion that the function of glial cells in general, and astrocytes in particular, was merely to provide trophic and structural support, with no relevant contribution to brain function, has been overcome by recent findings obtained using sophisticated experimental techniques. These findings demonstrate that astrocytes are active cellular players involved in the processing, transfer, and storage of information by the nervous system (Figure 2). In many cases, these findings have confirmed experimentally many of the original ideas proposed by Cajal regarding the physiological significance of neuroglia.

"El prejuicio de que las fibrillas neuróglicas son a las células nerviosas lo que los haces colágenos del tejido conectivo a los corpúsculos musculares o glandulares, es decir, una trama pasiva de mero relleno y de sostén (y cuando más, una ganga destinada a embeberse en jugos nutritivos), constituye sin duda el principal obstáculo que el observador necesita remover para formarse un concepto racional de la actividad de los corpúsculos neuróglicos." (The prejudice that the relation between neuroglial fibers and neuronal cells is similar to the relation between connective tissue and muscle or gland cells, that is, a passive for merely filling and support 
(and in the best case, a gangue for taking nutritive juices), constitutes the main obstacle that the researcher needs to remove to get a rational concept about the activity of the neuroglia) (Ramón y Cajal, 1899).

\section{REFERENCES}

Araque, A., Carmignoto, G., Haydon, P. G., Oliet, S. H., Robitaille, R., and Volterra, A. (2014). Gliotransmitters travel in time and space. Neuron 81, 728-739. doi: 10.1016/j.neuron.2014.02.007

Araque, A., and Navarrete, M. (2010). Glial cells in neuronal network function. Philos. Trans. R. Soc. B Biol. Sci. 365, 2375-2381. doi: 10.1098/rstb.2009.0313

Araque, A., Parpura, V., Sanzgiri, R. P., and Haydon, P. G. (1999). Tripartite synapses: glia, the unacknowledged partner. Trends Neurosci. 22, 208-215. doi: 10.1016/S0166-2236(98)01349-6

Bélanger, M., Allaman, I., and Magistretti, P. J. (2011). Brain energy metabolism: focus on astrocyte-neuron metabolic cooperation. Cell Metab. 14, 724-738. doi: 10.1016/j.cmet.2011.08.016

Carmignoto, G., and Gomez-Gonzalo, M. (2010). The contribution of astrocyte signalling to neurovascular coupling. Brain Res. Rev. 63, 138-148. doi: 10.1016/j.brainresrev.2009.11.007

Charles, A. C., Merrill, J. E., Dirksen, E. R., and Sanderson, M. J. (1991). Intercellular signaling in glial cells: calcium waves and oscillations in response to mechanical stimulation and glutamate. Neuron 6, 983-992. doi: 10.1016/08966273(91) $90238-\mathrm{U}$

Cornell-Bell, A. H., Finkbeiner, S. M., Cooper, M. S., and Smith, S. J. (1990). Glutamate induces calcium waves in cultured astrocytes: long-range glial signaling. Science 247, 470-473. doi: 10.1126/science. 1967852

De Felipe, J. (2011). The evolution of the brain, the human nature of cortical circuits, and intellectual creativity. Front. Neuroanat. 5:29. doi: 10.3389/fnana.2011.00029

Golgi, C. (1903). Opera. Omnia 2, 460.

Halassa, M. M., Fellin, T., and Haydon, P. G. (2009). Tripartite synapses: roles for astrocytic purines in the control of synaptic physiology and behavior. Neuropharmacology 57, 343-346. doi: 10.1016/j.neuropharm. 2009.06.031

Herculano-Houzel, S. (2012). The remarkable, yet not extraordinary, human brain as a scaled-up primate brain and its associated cost. Proc. Natl. Acad. Sci. U.S.A. 109, 10661-10668. doi: 10.1073/pnas. 1201895109

Iadecola, C., and Nedergaard, M. (2007). Glial regulation of the cerebral microvasculature. Nat. Neurosci. 10, 1369-1376. doi: 10.1038/nn2003

Lewitus, E., Hof, P. R., and Sherwood, C. C. (2012). Phylogenetic comparison of neuron and glia densities in the primary visual cortex and hippocampus of carnivores and primates. Evolution 66, 2551-2563. doi: 10.1111/j.15585646.2012.01601.x

Matyash, V., and Kettenmann, H. (2010). Heterogeneity in astrocyte morphology and physiology. Brain Res. Rev. 63, 2-10. doi: 10.1016/j.brainresrev. 2009.12.001

Min, R., and Nevian, T. (2012). Astrocyte signaling controls spike timingdependent depression at neocortical synapses. Nat. Neurosci. 15, 746-753. doi: 10.1038/nn.3075

Navarrete, M., Perea, G., Fernandez De Sevilla, D., Gomez-Gonzalo, M., Nunez, A., Martin, E. D., et al. (2012). Astrocytes mediate in vivo cholinergic-induced synaptic plasticity. PLoS Biol. 10:e1001259. doi: 10.1371/journal.pbio.1001259

Navarrete, M., Perea, G., Maglio, L., Pastor, J., Garcia De Sola, R., and Araque, A. (2013). Astrocyte calcium signal and gliotransmission in human brain tissue. Cereb. Cortex 23, 1240-1246. doi: 10.1093/cercor/bhs122

Navarrete, M., and Araque, A. (2008). Endocannabinoids mediate neuronastrocyte communication. Neuron 57, 883-893. doi: 10.1016/j.neuron.2008. 01.029

Navarrete, M., and Araque, A. (2010). Endocannabinoids potentiate synaptic transmission through stimulation of astrocytes. Neuron 68, 113-126. doi: 10.1016/j.neuron.2010.08.043

Newman, E. A. (2013). Functional hyperemia and mechanisms of neurovascular coupling in the retinal vasculature. J. Cereb. Blood Flow Metab. 33, 1685-1695. doi: $10.1038 /$ jcbfm. 2013.145
Oberheim, N. A., Takano, T., Han, X., He, W., Lin, J. H., Wang, F., et al. (2009). Uniquely hominid features of adult human astrocytes. J. Neurosci. 29, 3276-3287. doi: 10.1523/JNEUROSCI.4707-08.2009

Oberheim, N. A., Wang, X., Goldman, S., and Nedergaard, M. (2006). Astrocytic complexity distinguishes the human brain. Trends Neurosci. 29, 547-553. doi: 10.1016/j.tins.2006.08.004

Perea, G., and Araque, A. (2006). Synaptic information processing by astrocytes. J. Physiol. (Paris) 99, 92-97. doi: 10.1016/j.jphysparis.2005.12.003

Perea, G., and Araque, A. (2010). Glia modulates synaptic transmission. Brain Res. Rev. 63, 93-102. doi: 10.1016/j.brainresrev.2009.10.005

Perea, G., Navarrete, M., and Araque, A. (2009). Tripartite synapses: astrocytes process and control synaptic information. Trends Neurosci. 32, 421-431. doi: 10.1016/j.tins.2009.05.001

Petzold, G. C., and Murthy, V. N. (2011). Role of astrocytes in neurovascular coupling. Neuron 71, 782-797. doi: 10.1016/j.neuron.2011.08.009

Porto-Pazos, A. B., Veiguela, N., Mesejo, P., Navarrete, M., Alvarellos, A., Ibanez, O., et al. (2011). Artificial astrocytes improve neural network performance. PLoS ONE 6:e19109. doi: 10.1073/pnas.111 2378108

Poskanzer, K. E., and Yuste, R. (2011). Astrocytic regulation of cortical UP states. Proc. Natl. Acad. Sci. U.S.A. 108, 18453-18458. doi: 10.1073/pnas.111 2378108

Ramón y Cajal, S. (1895). Algunas conjeturas sobre el mecanismo anatómico de la ideación, asociación y atención. Rev. Med. Cirug. Pr.c. 36, 3-14.

Ramón y Cajal, S. (1897). Algo sobre la significación fisiológica de la neuroglia. Revista Trimestral Micrografía 1, 3-47.

Ramón y Cajal, S. (1899). Textura del Sistema Nervioso del Hombre y de los Vertebrados. Tomo I: Imprenta y Librería de Nicolás Moya.

Ramón y Cajal, S. (1913). Contribución al conocimiento de la neuroglia del cerebro humano. Trab. Lab. Invest. Biol. XI, 225-315.

Sherwood, C. C., Stimpson, C. D., Raghanti, M. A., Wildman, D. E., Uddin, M., Grossman, L. I., et al. (2006). Evolution of increased glia-neuron ratios in the human frontal cortex. Proc. Natl. Acad. Sci. U.S.A. 103, 13606-13611. doi: 10.1073/pnas.0605843103

Suzuki, A., Stern, S. A., Bozdagi, O., Huntley, G. W., Walker, R. H., Magistretti, P. J., et al. (2011). Astrocyte-neuron lactate transport is required for long-term memory formation. Cell 144, 810-823. doi: 10.1016/j.cell.2011.02.018

Takata, N., Mishima, T., Hisatsune, C., Nagai, T., Ebisui, E., Mikoshiba, K., et al. (2011). Astrocyte calcium signaling transforms cholinergic modulation to cortical plasticity in vivo. J. Neurosci. 31, 18155-18165. doi: 10.1523/JNEUROSCI. 5289-11.2011

Volterra, A., and Meldolesi, J. (2005). Astrocytes, from brain glue to communication elements: the revolution continues. Nat. Rev. Neurosci. 6, 626-640. doi: $10.1038 / \mathrm{nrn} 1722$

Wang, X., Lou, N., Xu, Q., Tian, G. F., Peng, W. G., Han, X., et al. (2006). Astrocytic $\mathrm{Ca}^{2+}$ signaling evoked by sensory stimulation in vivo. Nat. Neurosci. 9, 816-823. doi: $10.1038 / \mathrm{nn} 1703$

Zorec, R., Araque, A., Carmignoto, G., Haydon, P. G., Verkhratsky, A., and Parpura, V. (2012). Astroglial excitability and gliotransmission: an appraisal of $\mathrm{Ca}^{2+}$ as a signalling route. ASN Neuro 4:e00080. doi: 10.1042/AN20110061

Conflict of Interest Statement: The authors declare that the research was conducted in the absence of any commercial or financial relationships that could be construed as a potential conflict of interest.

Received: 12 March 2014; paper pending published: 07 April 2014; accepted: 28 April 2014; published online: 19 May 2014.

Citation: Navarrete $M$ and Araque A (2014) The Cajal school and the physiological role of astrocytes: a way of thinking. Front. Neuroanat. 8:33. doi: 10.3389/fnana. 2014.00033

This article was submitted to the journal Frontiers in Neuroanatomy.

Copyright $\odot 2014$ Navarrete and Araque. This is an open-access article distributed under the terms of the Creative Commons Attribution License (CC BY). The use, distribution or reproduction in other forums is permitted, provided the original author $(s)$ or licensor are credited and that the original publication in this journal is cited, in accordance with accepted academic practice. No use, distribution or reproduction is permitted which does not comply with these terms. 